\title{
Natural Resource Exploitation and the Role of New Technology: a Case-history of the UK Herring Industry
}

\author{
by \\ DAVID J. WHITMARSH, MA (Exeter), \\ Principal Lecturer, Centre for the Economics and Management of Aquatic Resources, \\ Department of Economics, University of Portsmouth, \\ Locksway Road, Portsmouth PO4 8JF, England, UK, \\ Christopher A. ReID, PhD (Portsmouth), \\ Lecturer, Department of Economics, University of Portsmouth, \\ Locksway Road, Portsmouth PO4 8JF, England, UK, \\ ClifFord Gulvin, PhD (Edinburgh), \\ Principal Lecturer, Department of Economics, \\ University of Portsmouth, Locksway Road, Portsmouth PO4 8JF, England, UK, \\ $\&$ \\ MichaEl R. DUNN, \\ Head, Department of Economics, \\ University of Portsmouth, Locksway Road, Portsmouth PO4 8JF, England, UK.
}

\section{INTRODUCTION}

$\mathrm{T}$ he catching of Herrings (Clupea harengus) has historically been as important to the UK as it has to Europe as a whole, and the changes which have taken place in the industry have had major social and economic consequences for particular human communities. This paper explores the development of the UK herring industry from the 1960 s to the late 1970 s - a period characterized by radical improvements in the technology of capture as well as fundamental changes in fishing opportunities. As we hope to demonstrate, the herring industry provides a unique illustration of the economic and biological effects of technological change in situations where access to the natural resource remains virtually unrestricted. The paper also draws attention to the problem faced by policymakers in reconciling the aims of resource management with those of industrial efficiency and modernization.

The UK herring industry attained a peak of output immediately prior to World War I, when 577,000 tonnes were landed at ports around the British Isles (Wood \& Hopper, 1984 p. 13). The expansion which led up to this can be attributed to a favourable combination of circumstances which affected both supply and demand. On one hand, the use of steam power in place of sail power in driftnet vessels greatly increased the mobility and power of the herring fleet; on the other, the buoyancy of international markets helped to promote a profitable trade with a number of European countries, such that by 1913 nearly $75 \%$ of the Herrings caught in the UK were exported (ibid.p. 3).

The fortunes of the herring industry changed after World War I, largely as a result of the loss of European markets on which the herring trade was so reliant. The problem was aggravated by the inability of catching capacity to adjust to the lower level of demand; a symptom of this was that while UK herring catches fell by nearly $50 \%$ between 1929 and 1933, the number of vessels in the domestic fleet contracted by less than $10 \%$. The overcapitalization and accompanying financial distress prompted a Government enquiry into the state of the industry, which led to the setting up of the Herring Industry Board (HIB) in 1935 (Sea-fish Commission for the United Kingdom, 1934). The HIB saw its task as essentially a marketing one, and put forward a series of ambitious plans to promote Herring sales in the home and export markets, as well as attempting to rationalize capacity. By 1938 the situation had improved somewhat; both domestic consumption and export demand were higher than they had been 5 years previously, and much of the excess capacity had been eliminated. However, while markets for Herring showed some signs of having stabilized, the plight of the fishermen involved appeared to have changed very little. The Elliot Report of 1944 commented that, despite the attempts made to reorganize the industry, 'the earnings of the herring fishing fleet continued to be exceedingly low up to outbreak of the War, and in many cases the fishermen did not earn sufficient to meet the proportion of voyage expenses.' (Scottish Home Department, 1944 p. 13).

After a period of prosperity following World War II, the herring industry experienced recurrent problems which the HIB did its best to ameliorate. These problems stemmed from the variability of supplies, the often poor quality of the raw material, and increased competition from other foodstuffs. Attempts to widen the range of market outlets met with some success, and the removal of surplus Herrings for reduction to fishmeal and oil helped to cope with the periodic gluts which had long been a feature of the industry. Indeed, by the 1960 s the difficulties created by excess supply and low prices had come to be regarded as of lesser importance compared with the failure to satisfy demand during times of scarcity, and for this reason the HIB formed the opinion that the fundamental problem of the industry was one of undersupply (Herring Industry Board, 1962 p. 3, 1966 p. 21). The solution, as they saw it, was to expand domestic production of Herring; this would not be accomplished, however, 'unless fishing methods capable of securing a larger catch per unit of effort are adopted' (Herring Industry Board, 1966 p. 22).

Accordingly, the HIB saw its role as being to encourage awareness and use by British herring fishermen of more effective techniques of capture, and to remove all obstacles to their successful adoption. The apparent success of this policy, at least in its first few years, is illustrated in Fig. 1, which indicates that landings by British vessels, which had been on a downward trend throughout the 1950s and early 


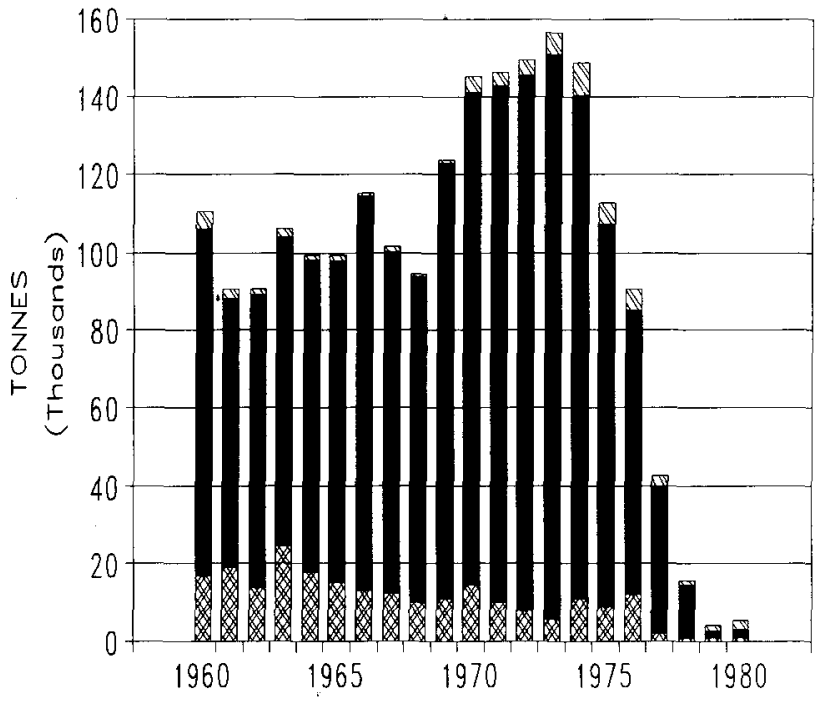

E \&W SCOTLAND MN.I.

FIG. 1. The UK herring industry: 'national' landings by British vessels.

1960 s, increased by almost two-thirds over the period 1968-73. This level of production could not be sustained, however, and during the late 1970s landings fell sharply, so that by 1979 the industry was producing a mere $3 \%$ of what it had been in 1973 .

The question which inevitably arises is whether the collapse of the herring fisheries, that took place in the late 1970 s, was a consequence of the rapid expansion which preceded it. To investigate this we first of all examine the details of the new technology which began to penetrate the industry during the 1960s, and follow this examination with an analysis of the natural resource and of the pattern of harvesting.

\section{Technological Change After 1960}

In the early 1960s it was suggested that drift-netting, which was the traditional method used by British fishermen to capture Herring, had become outmoded and inefficient, and that there was much to be gained from adopting more modern fishing techniques which were being used with success by foreign fleets (Herring Industry Board, $1962 \mathrm{p}$. 47). Drift-netting is essentially a passive method of fishing whereby a series of nets are suspended in the water from the vessel (Fig. 2) and in which the Herring become entrapped by the gills. Although for many years drift-netting was regarded as the best all-round method available, its relatively high labour requirements and low productivity made it increasingly less attractive in an age when manpower was becoming more difficult to obtain. The other main method of fishing for Herring at that time, ringnetting, ${ }^{*}$ was largely restricted to use in sheltered waters or close to shore, and for this reason it was not realistic to expect substantially increased quantities of Herring to be forthcoming from vessels employing this technique. Clearly, the solution to the supposed 'undersupply' pro-

* An encircling method of netting, typically employing two vessels. - Ed.

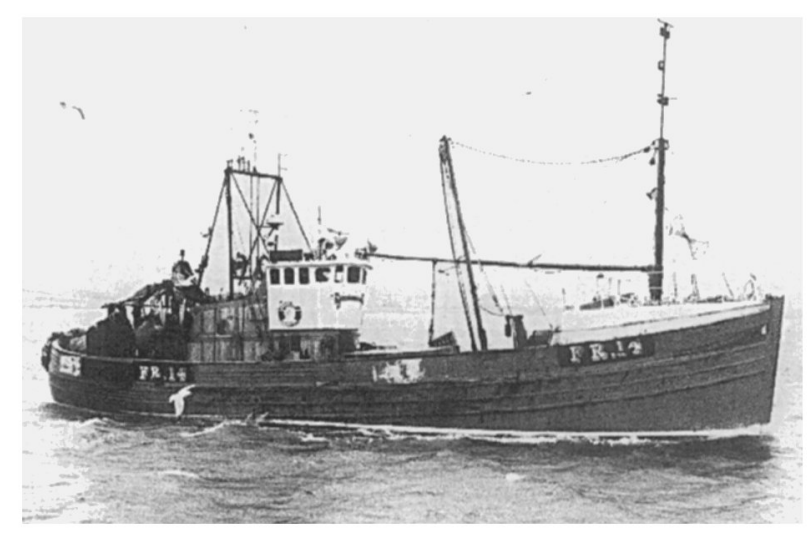

FIG. 2. A traditional herring vessel, originally built for drift-netting, but now converted to using other methods. Photo: Ian Leask.

blem had to be found elsewhere.

In considering the alternatives to drift-netting, interest initially centred on trawling. Trawling for Herring has been practised in the UK for many years, but its effectiveness was limited by the fact that the traditional technique of 'bottom' trawling could only be used to capture Herring during those hours of the day when the shoals were close to the sea-bed. It was recognized that if Herrings were to be taken in reasonable quantities in mid-water, the gear would have to be adapted. With financial support from the British Government, the HIB in the early 1960s sponsored trials aimed at investigating the feasibility of mid-water gear as well as bottom trawls. Though the results of the trials were mixed, enough interest was generated amongst fishermen for a number of them to experiment with, and eventually adopt, trawling on a commercial basis.

Trawling was not the only alternative to drift-netting, however. Purse-seining, $\uparrow$ a method in which a net is used to encircle complete shoals of Herring, has been used with success by Norwegian fishermen to exploit the Shetland herring grounds; indeed, so visibly effective was this method that in 1965 approaches were made to the HIB by British fishermen for financial assistance to convert their existing vessels for use as purse-seiners (Herring Industry Board, 1966 p. 14). Though hesitant at first to give unqualified approval to the new technique, the Board in 1966 announced that it had given financial assistance to two Scottish boats to undertake purse-seining; it also reported that a number of boat-owners had already decided to go ahead and build new vessels equipped for purse-seining, and that others were 'actively considering the conversion of existing drifters' (Fig. 3 and $c f$. Herring Industry Board, 1967 p. 13).

The diffusion of trawling proceeded very rapidly throughout the late 1960s, such that between 1965 and 1970 the proportion of UK Herring taken by trawlers had risen from 5\% to 55\%. (Fig. 4). The use of purse-seining also became more widespread, though, partly because of its later introduction, by 1970 it accounted for only $15 \%$ of UK landings of Herring. By 1973, however, this proportion had more than doubled to $37 \%$. Drift-netting and ring-

$\dagger$ In answer to our query, the first-named Author replied that in this method the "power was greatly enhanced by the use of hydraulic power-blocks for hauling the net and its contents from the water.' Ed. 


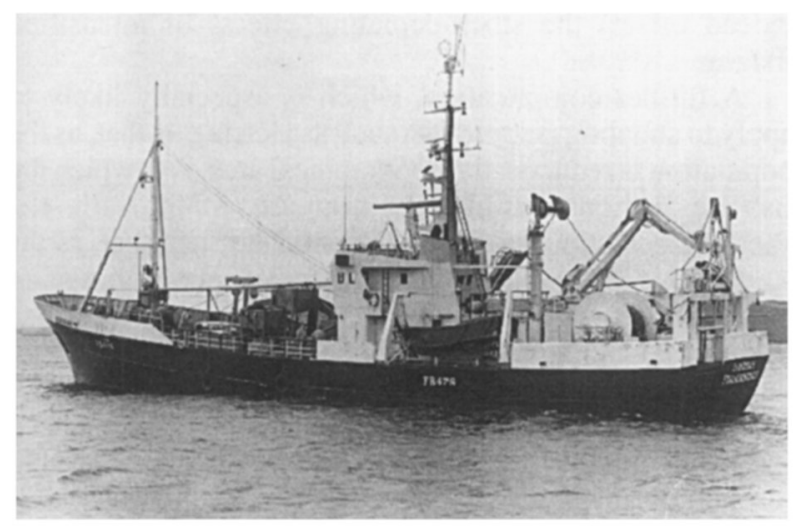

FIG. 3. A modern purse-seiner. Photo: Ian Leask.

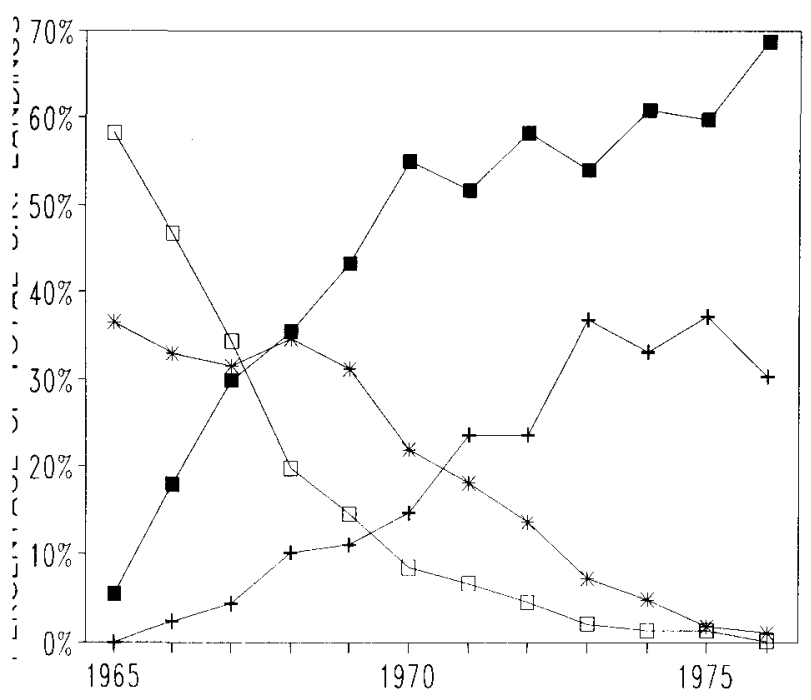

- TRAWL + PURSE * RING - - CRIFT

FIG. 4. Diffusion of innovations: method used by UK herring fishermen.

netting each underwent, respectively, an absolute and relative decline over the period, and by the mid-1970s these traditional methods had all but disappeared (ibid.). Within the space of a decade, therefore, the technological basis of the industry had changed fundamentally in the UK and elsewhere.

Several factors affected this transition. Experience of using trawling and purse-seining soon established their superiority over existing practices, and this was reinforced by a powerful demonstration effect: the catching power of the new techniques could be seen and attested to. Data published by the Department of Agriculture and Fisheries for Scotland (1979) allow us to draw comparisons between the productivity of herring vessels exploiting the Scottish west coast fishing-grounds over the period 1966-77 (Fig. 5). Trawling achieved higher catches per day than driftnetting and ring-netting, while purse-seining stands out as being markedly more efficient than any of the other methods. Indeed, the catching power of an average purseseiner is almost six times that of a drift-netter. To some

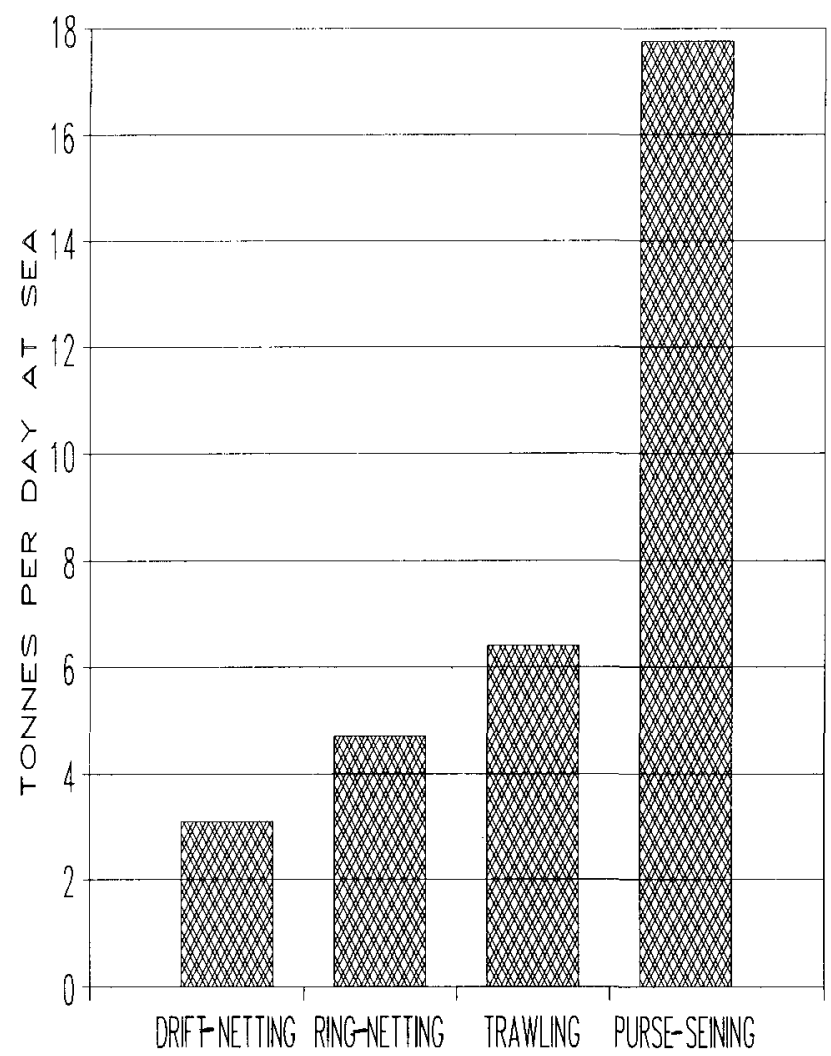

FIG. 5. Productivity of herring fishing methods: average catch-rated, 1966-77.

extent this latter result can be explained in terms of vessel size; it has been estimated, for example, that compared with a drift-netter, the average gross tonnage of a purse-seiner was about two-and-a-half times as great and its crew requirement roughly double (Cunningham et al., 1985 p. 60). Quite clearly, however, even when these size factors are taken into account, a substantial productivity differential remains between purse-seining and drift-netting. Such differences in physical performance were made all the more conspicuous by the geographical mobility of the vessels and their crews, which resulted in a high degree of interaction between innovators and non-innovators. In these circumstances it was difficult to conceal what to many observers were the half-evident advantages of the new techniques.

The HIB facilitated the innovation process in a number of ways, the most direct of which was through financial assistance for vessel construction and improvement. During the ten years from 1965 to 1975,144 applications for assistance towards the cost of building new boats were received by the Board, and 118 offers of assistance were made. This involved a total of $£ 5.9 \mathrm{~m}$ in grants and $£ 5.7 \mathrm{~m}$ in loans, the bulk of which went towards the construction of vessels designed for trawling, purse-seining, or operation as multipurpose craft. In parallel with this the Board awarded a large number of grants and loans for the modernization and upgrading of vessels with new gear and equipment, all of which contributed to the catching power of the herring fleet.

Possibly of greater significance than even the direct assistance given to capital investment were the active steps 
taken by the HIB to engender a favourable climate of opinion towards new technology, and in particular the efforts made to dismiss suggestions that the new fishing methods were destructive of the natural resource. The 1967 Annual Report of the HIB, after referring with satisfaction to the growing use of trawling and purse-seining, also made mention of the concern expressed by Clyde fishermen that trawling was potentially damaging to the Herring and its spawn. While conceding that there might be a threat from the unrestricted use of trawling in that particular fishery, the Board insisted that in 'almost all other areas with which the Scottish industry is concerned, the spawning stocks are distributed much more widely and there is not the same potential danger to the stock as a whole which occurs on the Clyde' (Herring Industry Board, 1968 p. 11).

The latter contention begs the question of whether the HIB fully appreciated the real significance of the changes which they were helping to bring about by making the capture of Herring more profitable, whereupon fishing activity would intensify and increased pressure would be imposed on the existing stocks. The extent to which this intensification took place, and the consequences which it had for the fisheries, are examined in the next section.

\section{Effects of Technological Change}

\section{Theoretical Consequences}

In most bioeconomic models of fish populations exploited under open-access conditions, it is conventionally assumed that labour and capital will enter a fishery if any profit is expected to be eamed, and will likewise exit from the fishery if losses are anticipated (Clark, 1976; Cunningham \& Whitmarsh, 1981). The adoption of a new and more efficient method of harvesting (or any other technical improvement which lowers the unit costs of production) can be expected to result in a short-run improvement in profitability for those fishermen who avail themselves of the opportunity. By assumption, however, this very success would serve to encourage others to innovate and enter the fishery in pursuit of the mirage of profit, and this process will be given added impetus as established fishermen, using traditional fishing methods, may find it worth while to switch from the old technology to the new (Whitmarsh, 1990).

With such switching, the fish-stocks will become more and more heavily depleted as a result of intensified fishing, and this will be reflected in a decline in catch-rates for all participating vessels. Stock depletion thus imposes an external cost on fishermen. So long as the innovation process continues, and while there is any profit still to be gained, the biological exploitation of the fishery will become more intensified and result in a progressive deterioration of the natural resource. Sustainable yield can be expected to increase throughout the early stages of the development of the fishery - until a finite maximum is reached (the maximum sustainable yield); but it will subsequently fall below this level as stock depletion becomes severe.

The scenario we have just described may be modified by a number of other influences, including changes in the fish population which are unconnected with the effects of fishing. In reality, the biomass of the adult fish-stock will fluctuate from year to year, due to variations in the relative abundance of juvenile fish recruited to the fishery. A series of good year-classes, for example, may well conceal (and indeed offset) the stock-depleting effects of intensified fishing.

A further complication, which is especially likely to apply to shoaling pelagic fish such as Herring, is that, as the population is reduced, the geographical area over which the fish are distributed is likely to decrease. Additionally, the shoaling behaviour of the species may be such that, as the stock size decreases, the fish form fewer schools but of an average size similar to that which previously obtained (Csirke, 1988). Both these effects may make the fish more vulnerable to capture by certain methods of fishing, with the result that the decline in the fish population may not be fully reflected in the decline in individual vessels' catchrates. Indeed, for some types of vessel, catch-rates may hold up quite well in the face of stock depletion, leading to the very real risk that the population may be fished to near extinction.

\section{Empirical Evidence on Productivity and Stock Abundance}

Herrings are distributed over an extended area of the Continental Shelf in the Northeast Atlantic, and from earliest times fleets from several European countries have participated in their exploitation. The two most important concentrations of Herrings are those situated off the Northwest coast of Norway, known as the AtlantoScandian stock, and those located in the North Sea and to the West of Britain (Coull, 1988). Within each group there is a characteristic pattern of spawning and migration, which in the past has had an important bearing on the way fishing operations have been conducted. The wide area of distribution and the migratory nature of the Herring have also had implications for the assessment and regulation of the fisheries, as catches in a particular area may consist of Herrings from more than one stock. In particular, this complicates the task of deciding what would be the most appropriate level of fishing effort in a given region of capture, because for management purposes catches need to be matched to the stock from which they are harvested. Fisheries management is made more complicated still by the existence of sub-stocks, such as those which are now believed to exist in the North Sea.

As might be expected, the more remotely situated Atlanto-Scandian stock of Herring has been a less important source of supply to the UK than those found in closer proximity to the British Isles, notably off the West of Scotland (Table I). The West of Scotland fishery is of particular significance in the present context, not only because it was to become the major supplier of Herrings to the UK but also because, for much of the period of the $1960 \mathrm{~s}$ and $1970 \mathrm{~s}$, the UK accounted for the bulk of international landings from this region. Indeed, Table II shows clearly that UK involvement with the herring fisheries to the West of the country was far higher than it was elsewhere. The condition of the western stocks is therefore likely to have been affected by the activities of UK vessels to a much greater degree than the other herring stocks in the Northeast Atlantic.

Table III analyses the changes which took place in the West of Scotland herring fishery from 1967 to 1977 , the period which saw the sharpest rise and fall in fishing activity. The fishery expanded very rapidly in the late 1960 s, to reach a peak of landings in 1973; but this was more than matched by the fall in landings which took place in the years that followed. The UK was the leading 
TABLE I

The UK Herring Industry: Regions of Capture.

Nominal Catches (TONNES)

\begin{tabular}{|c|c|c|c|c|c|}
\hline & 1960 & 1965 & 1970 & 1975 & 1980 \\
\hline \multicolumn{6}{|l|}{ NORTH SEA } \\
\hline England \& Wales & 16,265 & 11,441 & 9,528 & 6,344 & 48 \\
\hline Scotland & 29,911 & 28,109 & 22,768 & 8,741 & 38 \\
\hline N. Ireland & 0 & 0 & 0 & 0 & 0 \\
\hline Total UK & 46,176 & 39,550 & 32,296 & 15,085 & 86 \\
\hline \multicolumn{6}{|l|}{ WEST of SCOTLAND } \\
\hline England \& Wales & 36 & 28 & 0 & 125 & 33 \\
\hline Scotland & 58,921 & 53,909 & 103,530 & 89,298 & 2,084 \\
\hline N. Ireland & 0 & 0 & 1 & 6 & 0 \\
\hline Total UK & 58,957 & 53,937 & 103,531 & 89,429 & 2,117 \\
\hline \multicolumn{6}{|l|}{ IRISH SEA } \\
\hline England \& Wales & 412 & 2,681 & 4,631 & 1,825 & 737 \\
\hline Scotland & 696 & 671 & 416 & 441 & 14 \\
\hline N. Ireland & 4,668 & 1,702 & 4,353 & 5,612 & 2,450 \\
\hline Total UK & 5,776 & 5,054 & 9,400 & 7,879 & 3,201 \\
\hline \multicolumn{6}{|l|}{ OTHER REGIONS } \\
\hline England \& Wales & 162 & 1,149 & 394 & 247 & 61 \\
\hline Scotland & 7 & 4 & 0 & 25 & 101 \\
\hline N. Ireland & 0 & 0 & 0 & 0 & 0 \\
\hline Total UK & 169 & 1,153 & 394 & 272 & 162 \\
\hline Total all Regions & 111,078 & 99,694 & 145,621 & 112,665 & 5,566 \\
\hline
\end{tabular}

Sources: ICES (1962) Bulletin Statistique des Pêches Maritimes, Vol. 45, Copenhagen, Denmark: 61 pp., illustr. ICES (1967) Bulletin Statistique des Pêches Maritimes, Vol. 50, Copenhagen, Denmark: 74 pp., illustr. ICES (1972) Bulletin Statistique des Pêches Maritimes, Vol. 60, Copenhagen, Denmark: 175 pp., illustr. ICES (1982) Bulletin Statistique des Pêches Maritimes, Vol. 65, Copenhagen, Denmark: 103 pp., illustr.

TABLE II

UK Participation in European Herring Grounds. Nominal Catches (TONNES)

\begin{tabular}{|c|c|c|c|c|c|}
\hline & 1960 & 1965 & 1970 & 1975 & 1980 \\
\hline $\begin{array}{l}\text { NORTH SEA } \\
\text { UK } \\
\text { Other nations } \\
\text { Total }\end{array}$ & $\begin{array}{r}46,176 \\
740,774 \\
786,950\end{array}$ & $\begin{array}{r}39,550 \\
1,190,765 \\
1,230,315\end{array}$ & $\begin{array}{r}32,296 \\
716,454 \\
748,750\end{array}$ & $\begin{array}{r}15,085 \\
280,222 \\
295,307\end{array}$ & $\begin{array}{r}86 \\
12,161 \\
12,247\end{array}$ \\
\hline$\% \mathrm{UK}$ & 5.9 & 3.2 & 4.3 & 5.1 & 0.7 \\
\hline $\begin{array}{l}\text { WEST OF SCOTL } \\
\text { North Sea } \\
\text { UK } \\
\text { Other nations } \\
\text { Total }\end{array}$ & $\begin{array}{r}58,957 \\
9,273 \\
68,230\end{array}$ & $\begin{array}{l}53,937 \\
12,446 \\
66,383\end{array}$ & $\begin{array}{r}103,531 \\
53,506 \\
157,037\end{array}$ & $\begin{array}{r}89,429 \\
52,967 \\
142,396\end{array}$ & $\begin{array}{r}2,117 \\
8,957 \\
11,074\end{array}$ \\
\hline$\% \mathrm{UK}$ & 86.4 & 81.3 & 65.9 & 62.8 & 19.1 \\
\hline $\begin{array}{l}\text { IRISH SEA } \\
\text { UK } \\
\text { Other nations } \\
\text { Total }\end{array}$ & $\begin{array}{r}5,776 \\
16,059 \\
21,835\end{array}$ & $\begin{array}{r}5,054 \\
5,025 \\
10,079\end{array}$ & $\begin{array}{r}9,400 \\
5,884 \\
15,284\end{array}$ & $\begin{array}{r}7,879 \\
25,147 \\
33,026\end{array}$ & $\begin{array}{r}3,201 \\
12,046 \\
15,247\end{array}$ \\
\hline$\%$ UK & 26.5 & 50.1 & 61.5 & 23.9 & 21 \\
\hline $\begin{array}{l}\text { OTHER REGIONS } \\
\text { UK } \\
\text { Other nations } \\
\text { Total }\end{array}$ & $\begin{array}{r}169 \\
1,519,474 \\
1,519,643\end{array}$ & $\begin{array}{r}1,153 \\
2,267,707 \\
2,268,860\end{array}$ & $\begin{array}{r}394 \\
499,028 \\
499,422\end{array}$ & $\begin{array}{r}272 \\
605,564 \\
605,836\end{array}$ & $\begin{array}{r}162 \\
636,668 \\
636,830\end{array}$ \\
\hline$\% \mathrm{UK}$ & 0.01 & 0.05 & 0.08 & 0.04 & 0.03 \\
\hline $\begin{array}{l}\text { ALL REGIONS } \\
\text { UK } \\
\text { Other nations } \\
\text { Total }\end{array}$ & $\begin{array}{r}111,078 \\
2,285,580 \\
2,396,658\end{array}$ & $\begin{array}{r}99,694 \\
3,475,943 \\
3,575,637\end{array}$ & $\begin{array}{r}145,621 \\
1,274,872 \\
1,420,493\end{array}$ & $\begin{array}{r}112,665 \\
963,900 \\
1,076,565\end{array}$ & $\begin{array}{r}5,566 \\
669,832 \\
675,398\end{array}$ \\
\hline$\%$ UK & 4.6 & 2.8 & 10.3 & 10.5 & 0.8 \\
\hline
\end{tabular}

Sources: ICES (1962) Bulletin Statistique des Pêches Maritimes, Vol. 45, Copenhagen, Denmark: 61 pp., illustr. ICES (1967) Bulletin Statistique des Pêches Maritimes, Vol. 50, Copenhagen, Denmark: 74 pp., illustr. ICES (1972) Bulletin Statistique des Pêches Maritimes, Vol. 60, Copenhagen, Denmark: 175 pp., illustr. ICES (1982) Bulletin Statistique des Pêches Maritimes, Vol. 65, Copenhagen, Denmark: 103 pp., illustr. 
TABLE III

West of Scotland Herring Fishery, 1967-77.

\begin{tabular}{lcccc}
\hline Year & $\begin{array}{c}\text { International } \\
\text { Catches } \\
\text { (tonnes) }\end{array}$ & $\begin{array}{c}\text { UK } \\
\text { Catches } \\
\text { (tonnes) }\end{array}$ & $\begin{array}{c}\text { Fishing } \\
\text { Mortality } \\
\text { Rate }\end{array}$ & $\begin{array}{c}\text { Fish-stock } \\
\text { biomass } \\
\text { (tonnes) }\end{array}$ \\
\hline 1967 & 102,694 & 67,404 & 0.22 & 451,000 \\
1968 & 100,323 & 65,187 & 0.20 & 450,000 \\
1969 & 123,593 & 90,225 & 0.30 & 510,000 \\
1970 & 157,037 & 103,531 & 0.35 & 513,000 \\
1971 & 226,310 & 104,922 & 0.66 & 489,000 \\
1972 & 197,181 & 112,203 & 0.45 & 667,000 \\
1973 & 244,771 & 127,638 & 0.63 & 603,000 \\
1974 & 203,741 & 111,547 & 0.82 & 377,000 \\
1975 & 142,396 & 89,429 & 0.89 & 225,000 \\
1976 & 111,800 & 57,590 & 1.11 & 172,000 \\
1977 & 54,538 & 30,371 & 0.8 & 82,000 \\
\hline
\end{tabular}

Sources:

ICES (1969) Bulletin Statistique des Pêches Maritimes, Vol. 52, Copenhagen, Denmark: 76 pp., illustr.

ICES (1970) Bulletin Statistique des Pêches Maritimes, Vol. 53, Copenhagen, Denmark: 77 pp., illustr.

ICES (1971) Bulletin Statistique des Pêches Maritimes, Vol. 54, Copenhagen, Denmark: 77 pp., illustr.

ICES (1972) Bulletin Statistique des Pêches Maritimes, Vol. 55, Copenhagen, Denmark: 78 pp., illustr.

ICES (1973) Bulletin Statistique des Pêches Maritimes, Vol. 56, Copenhagen, Denmark: 77 pp., illustr.

ICES (1974) Bulletin Statistique des Pêches Maritimes, Vol. 57, Copenhagen, Denmark: 85 pp., illustr.

ICES (1976) Bulletin Statistique des Pêches Maritimes, Vol. 58, Copenhagen, Denmark: 163 pp., illustr.

ICES (1977) Bulletin Statistique des Pêches Maritimes, Vol. 59, Copenhagen, Denmark: 159 pp., illustr.

ICES (1978) Bulletin Statistique des Pêches Maritimes, Vol. 60, Copenhagen, Denmark: 175 pp., illustr.

ICES (1979) Bulletin Statistique des Pêches Maritimes, Vol. 61, Copenhagen, Denmark: 303 pp., illustr.

ICES (1980) Bulletin Statistique des Pêches Maritimes, Vol. 62 , Copenhagen, Denmark: 329 pp., illustr.

SAVILLE, A. \& BAlley, R. (1980). The assessment and management of the Herring Stocks in the North Sea and to the West of Scotland. Rapp. P.-v. Reun. Cons. Int. Explor. Mer, 177, Tables 2 and 3, p. 131.

Notes: Saville \& Bailey also present alternative estimates of fishing mortality up to 1975 which allow for emigration effects. The revised figures suggest that, for much of this period, the fishing mortality rate may have been greater than the data presented above would suggest.

participant in the herring fishery throughout the period, taking on average some $60 \%$ of total landings. Scientific evidence to support the suggestion that the development of the fishery had a significant impact on the natural resource is revealed by the data on the fishing mortality rate and the biomass of the fish-stock. Fishing mortality showed a marked tendency to increase after 1968, which in itself would have contributed to the depletion of the fish-stock. The fact that stock depletion did not become clearly apparent until after 1972 can be explained by a succession of good year-classes in the preceding years, which caused the estimated fish-stock biomass to rise to a peak of 667,000 tonnes. Recruitment of juvenile fish to the adult stock was generally much weaker after 1973, however, which in combination with the increasing pressure of fishing undoubtedly led to the dramatic fall in the fishstock biomass that eventually took place (Saville \& Bailey, 1980).
The externalities of this collapse are highlighted in the data on UK vessel catch-rates, which fell very sharply after 1973 (Table IV). The figures confirm the fact that pelagic trawlers and purse-seiners generally achieved higher catchrates than drift-netters and ring-netters, but also show that none of these vessel types was immune from the effects of stock depletion. For drift-netters the decline in productivity took place fairly steadily over a number of years, whereas for the other types of vessel the decline took place in a much shorter period of time and with correspondingly greater severity. By 1977, trawlers were averaging 2.6 tonnes per day at sea - a mere $30 \%$ of what they had been catching 10 years previously, and indeed significantly below the average physical performance achieved by driftnetters and ring-netters in the 1960s.

The reason why the herring stocks were not prevented from falling to such low levels was due to the fact that,

$$
\text { TABLE IV }
$$

Catch-rates of British Herring Vessels on Scottish West Coast, 1967-77.

Catch Per Day at Sea (tonnes)

\begin{tabular}{lcccc}
\hline Year & $\begin{array}{c}\text { Drift- } \\
\text { netters }\end{array}$ & $\begin{array}{c}\text { Ring- } \\
\text { netters }\end{array}$ & $\begin{array}{c}\text { Pelagic } \\
\text { Trawlers }\end{array}$ & $\begin{array}{c}\text { Purse- } \\
\text { seiners }\end{array}$ \\
\hline 1967 & 5.07 & 3.73 & 8.63 & 12.40 \\
1968 & 4.21 & 4.62 & 6.34 & 8.69 \\
1969 & 4.19 & 5.12 & 7.34 & 14.77 \\
1970 & 3.85 & 4.89 & 6.44 & 16.41 \\
1971 & 4.44 & 4.80 & 7.17 & 21.58 \\
1972 & 3.09 & 6.19 & 8.38 & 22.70 \\
1973 & 1.54 & 5.65 & 6.98 & 36.16 \\
1974 & 1.58 & 5.70 & 6.01 & 24.70 \\
1975 & 1.58 & 5.84 & 4.84 & 19.85 \\
1976 & 1.17 & 4.96 & 4.24 & 13.22 \\
1977 & 1.33 & 1.17 & 2.60 & 6.70 \\
$\ldots .$. & & & &
\end{tabular}

Sources:

DEPARTMENT of Agriculture AND Fisheries FOR SCOTLANd (1969), Scottish Sea Fisheries Statistical Tables 1968, HMSO, Edinburgh, UK: $53 \mathrm{pp}$.

DEPARTMENT OF AGRICULTURE AND Fisheries FOR SCOTLAND (1970), Scottish Sea Fisheries Statistical Tables 1969, HMSO, Edinburgh, UK: $53 \mathrm{pp}$.

DePartment of Agriculture and Fisheries for SCOTLANd (1971), Scottish Sea Fisheries Statistical Tables 1970, HMSO, Edinburgh, UK: $53 \mathrm{pp}$.

DEPARTMENT OF AGRICULTURE AND FisherIES FOR SCOTLAND (1972), Scottish Sea Fisheries Statistical Tables 1971, HMSO, Edinburgh, UK: $48 \mathrm{pp}$.

Department of Agriculture and Fisheries for SCOTland (1973), Scottish Sea Fisheries Statistical Tables 1972, HMSO, Edinburgh, UK: $48 \mathrm{pp}$.

DePartment OF AgRiculture AND Fisheries For SCOTLAND (1974), Scottish Sea Fisheries Statistical Tables 1973, HMSO, Edinburgh, UK: $48 \mathrm{pp}$.

DEPARTMENT OF AGRICULTURE AND FisheriEs FOR SCOTLAND (1975), Scottish Sea Fisheries Statistical Tables 1974, HMSO, Edinburgh, UK: $47 \mathrm{pp}$.

DePartment of Agriculture ANd Fisheries for SCOTLAND (1976), Scottish Sea Fisheries Statistical Tables 1975, HMSO, Edinburgh, UK: $54 \mathrm{pp}$

DEPARTMENT OF AGRICULTURE AND FISHERIES FOR SCOTLAND (1977), Scottish Sea Fisheries Statistical Tables 1976, HMSO, Edinburgh, UK: $56 \mathrm{pp}$.

DepartMent of Agriculture AND Fisheries for SCOTLANd (1978), Scottish Sea Fisheries Statistical Tables 1977, HMSO, Edinburgh, UK: 59 pp. 
throughout the 1960 s and 1970 s, control over the international fishing effort on the principal European fishinggrounds was almost non-existent. A system of Total Allowable Catches was introduced in 1974 by the Northeast Atlantic Fisheries Commission (NEAFC), but because the national quotas which were eventually agreed by NEAFC member countries were set too high, the effect was probably to intensify the pressure of fishing rather than to reduce it (Saville \& Bailey, 1980 p. 133). Not until 1977, the year in which responsibility for fisheries management within the newly-created 200 (nautical) miles $(370.4 \mathrm{~km}$ ) Exclusive Economic Zone passed to the European Economic Community (EEC), was a ban on excessive fishing of Herring eventually agreed to. This was imposed first on herring fishing in the North Sea, followed one year later by a similar ban on the West of Scotland fishery (Wood \& Hopper, 1984). Up until the late 1970s, therefore, the herring fisheries retained their essentially open-access character, and it is hardly surprising that in this situation the intensification of fishing activity brought about by advances in technology should have had an adversely visible effect on both the natural resource and its industrial productivity.

\section{Economic Implications}

The failure to control the expansion of fishing effort also meant that any resource-rent (see below) which the herring fisheries might have generated would be dissipated. In this context resource-rent can be defined as the difference between the value of output and the opportunity cost of the labour and capital inputs (i.e. fishermen, vessels, plant, and equipment) devoted to or resulting from the activity of harvesting. As such it represents the net economic benefit which society could obtain from the fisheries. If the fish-stocks had been subject to property rights, this rent would have been collected by the resource owner, who in theory at least would have an incentive to regulate the amount of fishing so as to generate the maximum economic return on his natural asset. In practice, however, property-rights in the European herring fisheries - as with many other marine fisheries - do not exist, and hence the all-important imperative to control fishing effort is absent*. What happens, in effect, is that fishermen and others involved mistake resource-rent for profit, and as profits are competed away in the 'race for fish', so such 'rent' is inevitably dissipated.

The effect of introducing improved harvesting technology into a fishery is to increase its potential economic value by making it possible to produce output though using fewer input factors. This potential will only be realized, however, if the fishery can be managed in such a way as to capture the resource-rent. Where this is not the case, and the rent is allowed to dissipate, society effectively loses out on an important source of economic surplus. Rent dissipation thus implies a misallocation of resources, and this is reflected in the tendency for open-access fisheries to attract excessive units of labour and capital.

For the West of Scotland herring fishery no studies have hitherto been undertaken to measure its potential economic value, and the results presented here represent a first attempt to provide this information. It is beyond the scope of this paper to explain the full details of the

* As in the case of such 'commons' as the High Seas - see The Editorial opening our preceding issue. - Ed. methodology which underlies the results, but the essence of our approach has been to calculate the maximum sustainable resource-rent which could have been obtained from the fishery employing the 'best-practice' methods of fishing which were in use in the late 1970s. This was done by first of all estimating the functional relationship between sustainable yield and fishing effort, monetizing this function by the unit value of Herring, and then deducting from it the cost of fishing effort. Using the costs and prices which obtained in 1976 (the year preceding the collapse of the fishery), the highest level of resource-rent which could have been generated on a sustainable basis is estimated to be $£ 14$ millions per annum. As no resourcerent was ever actually obtained from the fishery, this figure therefore represents the stream of benefit lost to society owing to the failure to implement effective fisheries management.

\section{Comparisons With Other Fisheries}

The events described above are not unique, and other fisheries where technological change in harvesting has occurred tell a similar story. It has been observed elsewhere (Cunningham et al., 1985 p. 66) that, although many of the advances in fish-catching technology have often helped to bring about substantial improvements in catch-rates and profitability for individual operators, the aggregate effects have often proved contradictory. While there is no denying that technical progress may contribute to the growth and development of a fishery, it is also true that this same 'progress' may hasten its overexploitation and ultimate collapse. The Peruvian Anchoveta (Engraulis ringens) is a particularly spectacular example of where in the early 1970s landings suffered a sharp fall after a period of rapid expansion, and even though it is well known that oceanic factors were implicated in the collapse, it seems highly likely that the seeds of destruction had already been sown as a result of the build-up of excessive numbers of vessels (notably purse-seiners) of very great catching-power.

A further illustration of where fleet modernization appears to have had adverse effects is in Thailand, where the introduction of trawl technology has led to overcapitalization, depletion of the demersal stocks, and encroachment of distant-water trawlers onto coastal fishing grounds. In both these examples, as in the case of Herring, it may be contended that the problem was not technological change as such but the failure of public authorities to see at an early stage that the change needed to be brought within the remit of fisheries management.

What is distinctive about the case of Herring, however, is that it illustrates with sharp clarity how a fishery can finance its own demise. We have already established that the adoption of new catching methods increased the potential of the herring fishery to generate a resource-rent, but that the absence of a resource owner meant that this rent was never extracted. Instead, it was effectively used by the fishermen to pay for the expansion and upgrading of the fleet. The speed at which technological change took place in the herring fishery testifies to the fact that the resourcerent was, as we tried to demonstrate, of a 'non-trivial' amount. In a very real sense, therefore, the resource-rent provided a fund of money - additional to any funds coming from public authorities - which unwittingly came to be used to finance the overcapitalization of the fleet and the biological and economic consequences which followed. 


\section{CONCLUSION}

Advances in new fishing technology present policymakers with both an opportunity and a challenge. On the positive side, the opportunity exists to harvest fish-stocks using cost-effective methods which permit a genuine saving of labour and capital inputs. The economic benefits of so doing could, in principle, be captured in the form of increased resource-rent. The challenge, however, is to find some way of preventing the resource-rent from being dissipated as fishermen enter the fishery in pursuit of profit. Failure to control the expansion of effort not only leads to the dissipation of rent but also results in the depletion of the fish-stocks to a point where in some cases biological recovery is severely impaired.

On the basis of the evidence presented in this paper it might well be concluded that, in the case of the herring fisheries, the UK authorities saw only the opportunities which technological change offered, and failed to appreciate the challenge which it posed for fisheries management. We might be tempted to go further and argue that the steps taken by the Herring Industry Board to promote the adoption of new fishing techniques were misguided, given the economic and biological over-fishing which eventually resulted. The latter conclusion would be unjustified, however, as the HIB had little choice but to pursue the policy it did. We must appreciate that prior to 1977 , national governments had no real incentive to impose control measures on their domestic fleets, as to do so would have meant foregoing part of their share of the common property resource. In this situation it is hardly surprising that the emphasis of UK fisheries policy, as represented by the activities of the HIB, was placed upon fleet modernization and technological advance.

Accordingly the UK, in common with other national participants, was caught in a 'Prisoner's Dilemma': curbs on their own fishermen ran the risk that other nations might not exercise similar restraint and so be of no avail, while a strategy of unrestricted fishing ran the risk that the same tactic would be followed by competitors and result in overexploitation of the resource. Though the HIB was aware of the dilemma, it nevertheless came down in favour of a policy of 'taking all we can while the going's good' (Herring Industry Board, 1962 p. 4). This was further justified on the grounds that, even if such action did threaten a resource crisis, it would at least concentrate the minds of those who had responsibility for fisheries management and hasten the introduction of conservation measures. As events were to show, however, the Board's confidence in the ability of the authorities to manage the herring fisheries turned out to be sadly misplaced. It is ironic indeed that UK herring fishermen, whom the HIB did not wish to see disadvantaged in the race to obtain fish, faced the ultimate disadvantage of a resource crisis which forced many of them to look elsewhere for their livelihood.

\section{ACKNOWLEDGEMENTS}

The Authors would like to thank Dr Stephen Cunningham for his comments and suggestions on an earlier draft of this paper, which is based on research that was funded by the Economic and Social Research Council (ESRC), Reference Nr WB07250003.

\section{SUMMARY}

Technological change in the UK herring industry took place rapidly after 1965 , due in part to the active en- couragement given to fishermen to switch from driftnetting to pelagic trawling and purse-seining. The adoption and diffusion of these modern methods of capture stimulated a major expansion of output, but this very success was undermined by the depletion of the fish-stocks on which the industry depended. In the case of the West of Scotland herring fisheries, which were especially important to UK fishermen, the decline in fish-stock biomass caused vessel catch-rates to fall after 1973. The failure of international fisheries management, which acted as a permissive factor in the intensification of fishing effort, also had important economic implications as it resulted in the dissipation of resource-rent. The Authors calculate that the maximum sustainable 'rent' which could have been generated from the West of Scotland herring fishery was approximately $£ 14$ millions per annum at 1976-equivalent prices.

The resource-rent effectively financed the overcapitalization of the fleet and the decline which followed, and it is the speed with which this occurred that most distinguishes the herring fishery from others where technological change has taken place. The article concludes by arguing that, although the UK public authorities (notably the Herring Industry Board) might reasonably be criticized for pursuing a development strategy which resulted in economic and biological over-fishing, the international regime of fisheries management which prevailed at the time gave them little choice but to adopt a pro-active approach to technical innovation.

\section{REFERENCES}

Clark, C. (1976). Mathematical Bioeconomics, John Wiley \& Sons, New York, NY, USA: xi +342 pp., illustr.

Coull, J. (1988). The North Sea herring fishery in the Twentieth Century. Pp. 115-31 in Ocean Yearbook 7 (Eds E.M. BoRGESE, N. GINSBURG \& J.R. MORGAN). University of Chicago Press Ltd, London, England, UK: xi +621 pp., illustr.

Csirke, J. (1988). Small shoaling pelagic fish stocks. Pp. 271-302 in Fish Population Dynamics: Implications for Management, 2nd edn. (Ed. J.A. GulLand). J. Wiley \& Sons, New York, NY, USA: xviii + 422 pp., illustr.

Cunningham, S., Dunn, M.R. \& Whitmarsh, D. [J.] (1985). Fisheries Economics: An Introduction. Mansell Publishing Ltd, London, England, UK: xi + 372 pp., illustr.

CunNingham, S. \& WhitMarsh, D. [J.] (1981). When is Overfishing Underfishing? Environmental Management, 5(5), pp. 377-84.

Department of Agriculture AND Fisheries For SCOTLAND (1979). Scottish Sea Fisheries Statistical Tables 1978. HMSO Edinburgh, Scotland, UK: $63 \mathrm{pp}$.

HERRING INDUSTRY BOARD (1962). Twenty-Seventh Annual Report. Cmnd 1723, HMSO, London, England, UK: $51 \mathrm{pp}$.

HERRING INDUSTRY BOARD (1966). Thirty-first Annual Report. Cmnd 3003, HMSO, London, England, UK: $47 \mathrm{pp}$.

HERRING INDUSTRY BOARD (1967). Thirty-second Annual Report. Cmnd 3329, HMSO, London, England, UK: 46 pp.

HERRING INDUSTRY BOARD (1968). Thirty-third Annual Report. Cmnd 3642, HMSO, London, England, UK: 38 pp.

SAVILLE, A. \& BAILEY, R. (1980). The assessment and management of the Herring Stocks in the North Sea and to the West of Scotland. Rapp. P.-v. Reun. Cons. Int. Explor. Mer, 177, pp. 112-42.

SCOTTISH Home DePartment (1944). Report of the Committee on the Herring Industry. Cmnd 6503, HMSO, London, England, UK: $39 \mathrm{pp}$.

SeA-Fish COMmission for the United Kingdom (1934). First Report: The Herring Industry. Cmnd 4677, HMSO, London, England, UK: $51 \mathrm{pp}$.

WhITMARSH, D. [J.] (1990). Technological change and marine fisheries development. Marine Policy, 14(1), pp. 15-22.

WOOD, J. \& HOPPER, A. (1984). A Report on the UK Herring Fisheries in the 1980s. Sea Fish Industry Authority, Industrial Development Unit, Technical Report No. 245, Hull, England, UK: $38 \mathrm{pp}$. 